\title{
Fatigue as a presenting symptom of multiple myeloma
}

\author{
Multipl miyelomda başvuru semptomu olarak halsizlik
}

\author{
Umutcan Türk (1D, Yalkın Dalda (i), Aybüke Olgun (1), Harun Akar(i)
}

Department of Internal Medicine, University of Health Sciences, İzmir Tepecik Training and Research Hospital, İzmir, Turkey

\begin{abstract}
A 73-year-old man, without any significant previous history, presented to the Internal Medicine clinic with a one-year history of fatigue and weakness. As demonstrated in our case, the diagnosis of multiple myeloma (MM) presenting as fatigue requires a high degree of clinical suspicion.

Keywords: Fatigue, multiple myeloma, presenting signs, weakness.

ÖZ

Daha önce klinik öz geçmişi olmayan 73 yaşında bir erkek hasta son bir yıldır yorgunluk ve halsizlik öyküsü ile İç Hastalıkları Kliniğine başvurdu. Olgumuzda olduğu gibi, halsizlik olarak ortaya çıkan multipl miyelom (MM) tanısı yüksek derecede klinik şüphe gerektirir.
\end{abstract}

Anahtar sözcükler: Yorgunluk, multipl miyelom, başvuru semptomlar, halsizlik.

Multiple myeloma (MM) is a neoplastic plasma cell disease estimated to constitute approximately $1.6 \%$ of all cancers and $10 \%$ of hematological malignancies. ${ }^{[1]}$ Patients usually present with non-specific symptoms such as bone pain, fatigue, weakness, and recurrent infections, while many patients present with laboratory abnormalities such as anemia, renal failure, and high erythrocyte sedimentation rate or globulin levels. In the suspicion of $\mathrm{MM}$, the diagnostic workup should include erythrocyte sedimentation rate, serum creatinine, calcium, immunoglobulin levels, proteinuria in 24-hour urine, skeletal survey, and bone marrow assessment. ${ }^{[1]}$ In this report, we present a case who was hospitalized to investigate the etiology of fatigue and weakness and subsequently diagnosed as $\mathrm{MM}$ with the presence of severe anemia, hypercalcemia, albumin/globulin reversal, creatinine increase, prominent punched-out lytic lesions in skull X-ray and 50\% plasma cell in bone marrow aspiration. The patient was transferred to the Hematology clinic.

\section{CASE REPORT}

A 73-year-old male patient with known diagnoses of hypertension and coronary artery disease was admitted to the Internal Medicine clinic with a one-year history of progressive weakness. On physical examination, he was conscious, oriented, and cooperative. The rest of the physical examination was normal. Laboratory tests were as follows: white bood cell (WBC): 2,500/ $\mathrm{mm}^{3}$, hemoglobin: $7.8 \mathrm{~g} / \mathrm{dL}$, platelet: $160,000 / \mathrm{mm}^{3}$, alanine aminotransferase (ALT): $16 \mathrm{U} / \mathrm{L}$, aspartate aminotransferase (AST): $47 \mathrm{U} / \mathrm{L}$, lactate dehydrogenase (LDH): $625 \mathrm{U} / \mathrm{L}$, urea: $56 \mathrm{mg} / \mathrm{dL}$, creatinine: $1.4 \mathrm{mg} / \mathrm{dL}$, glomerular

Received: June 24, 2019 Accepted: August 27, 2019 Published online: October 31, 2019

Correspondence: Umutcan Türk. Sağlık Bilimleri Üniversitesi, İzmir Tepecik SUAM, İç Hastalıkları Kliniği, 35180 Yenişehir, Konak, İzmir, Türkiye. Tel: +90 545 - 2000068 e-mail: umutcannturk@gmail.com 


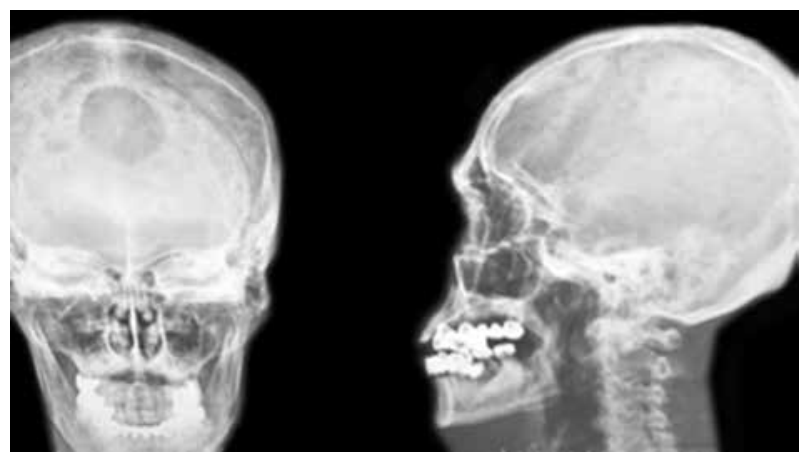

Figure 1. Multiple punched-out lytic lesions in skull X-ray.

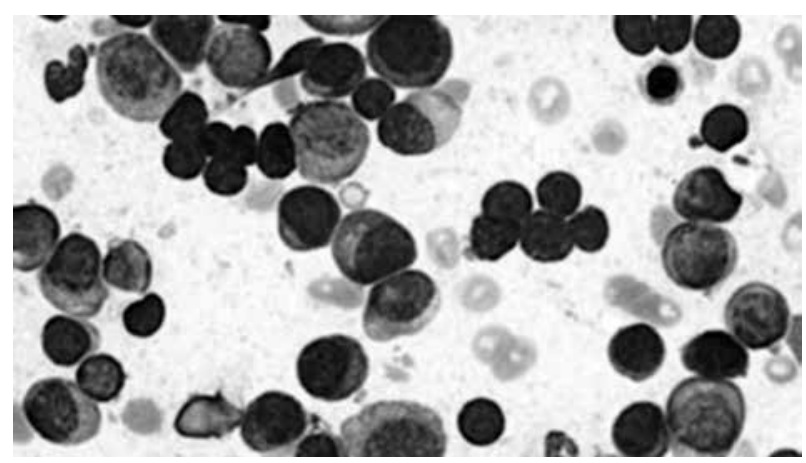

Figure 2. Bone marrow aspiration showed $50 \%$ plasma cell (Giemsa ×100).

filtration rate (GFR): $52.80 \mathrm{~mL} / \mathrm{min} / 1.73 \mathrm{~m}^{2}$, total protein: $10.3 \mathrm{~g} / \mathrm{dL}$, albumin: $2 \mathrm{~g} / \mathrm{dL}$, globulin: $8.3 \mathrm{~g} / \mathrm{dL}$, calcium: $12 \mathrm{mg} / \mathrm{dL}$, immunoglobulin (Ig)A: $6610 \mathrm{mg} / \mathrm{dL}$, IgG: $376 \mathrm{mg} / \mathrm{dL}$, IgM: $21.1 \mathrm{mg} / \mathrm{dL}$. Other laboratory values were within normal limits. Multiple punched-out lytic lesions were observed in the patient's skull X-ray (Figure 1). Bone marrow aspiration and biopsy showed $50 \%$ plasma cells in the aspiration of the patient (Figure 2). The patient was transferred to the hematology unit with the diagnosis of MM.

\section{DISCUSSION}

Since the symptoms that bring the MM patient to the physician are usually non-specific, early diagnosis may be a diagnostic challenge in primary care. Fatigue, weakness, back pain, weigh loss, or abnormal laboratory results are red flag warnings of $\mathrm{MM}$. Multiple myeloma has several symptoms similar to common patient complaints, which is why the disease may typically undiagnosed until it reaches the advanced stage. ${ }^{[2]}$ Back and lower back pain may be deformative and discogenic but may also be a sign of MM. Pain may be caused by a rheumatic pathology, but also from a large myelomatic osteolytic lesion that is prone to spontaneous fracture. ${ }^{[2]}$ Multiple myeloma is among the many causes of anemia and renal failure of unknown origin. Multiple myeloma should be considered in the differential diagnosis when investigating the causes of poor immunity, frequent infections, and hypercalcemia. ${ }^{[2]}$ Fatigue, weakness, drowsiness, and confusion can also be attributed to the prominent increase in the concentration of serum globulin (hyperviscosity), calcium levels, and anemia associated with MM..$^{[2,3]}$ Most anemic patients with MM suffer from moderate to severe fatigue. ${ }^{[4]}$ Replenishment of hemoglobin levels leads to improvement in fatigue and quality of life. Goldschmidt et al ${ }^{[5]}$ reported that $58 \%$ of MM patients had back pain and 34\% had complaints of fatigue or weight loss. In a study by Sultan et al. ${ }^{[6]}$ the most common presenting complaints were fatigue $(81.9 \%)$, back pain $(80.3 \%)$, and bone pain $(67.2 \%)$. Fuchs et al. ${ }^{[7]}$ suggested that an active investigation of paraproteinemia is indicated in cases of end-organ damage such as anemia, renal failure, recurrent infections, or prolonged fatigue. As $\mathrm{MM}$ has many different manifestations, it may sometimes present as severe fatigue and weakness. The workup of a patient with long standing weakness and fatigue of unknown cause should include immunofixation electrophoreses, free light chain assay, or bone marrow evaluation. ${ }^{[8]}$

As demonstrated in our case, long standing progressive fatigue and weakness together with anemia, decrease in GFR, albumin/globulin reversal, hypercalcemia and lytic lesion on direct $\mathrm{X}$-ray should be considered red flag warnings for MM.

Multiple myeloma presenting as prolonged fatigue and weakness requires a high degree of suspicion to avoid delay in diagnosis. Multiple myeloma should always be kept in mind in patients presenting with prolonged weakness and fatigue, exhaustion, deep anemia, hypercalcemia, and renal failure. ${ }^{[9]}$ Patients with long standing progressive fatigue and weakness of unknown etiology should be screened for possible plasma cell dyscrasia. 


\section{Declaration of conflicting interests}

The authors declared no conflicts of interest with respect to the authorship and/or publication of this article.

\section{Funding}

The authors received no financial support for the research and/or authorship of this article.

\section{REFERENCES}

1. Michels TC, Petersen KE. Multiple myeloma: Diagnosis and treatment. Am Fam Physician 2017;95:373-83.

2. Adam Z, Pourová E, Pour L, Michalková E, Krejcí M, Koukalová $\mathrm{R}$, et al. The patient complains of spinal pain or fatigue and weakness. How do I recognize whether their cause is spondylarthrosis, the patients age or multiple myeloma?. Vnitr Lek 2016;62:114-24. [Abstract]

3. Dalfardi B. A man with generalized weakness. Eur J Intern Med 2018;51:e7-e8.

4. Gascón P, Arranz R, Bargay J, Ramos F. Fatigueand health-related quality-of-life in anemic patients with lymphoma or multiple myeloma. Support Care Cancer 2018;26:1253-64.

5. Goldschmidt N, Zamir L, Poperno A, Kahan NR, Paltiel O. Presenting signs of multiple myeloma and the effect of diagnostic delay on the prognosis. J Am Board Fam Med 2016;29:702-9.

6. Sultan S, Irfan SM, Parveen S, Ali H, Basharat M. Multiple Myeloma: a Retrospective Analysis of 61 Patients from a Tertiary Care Center. Asian Pac J Cancer Prev 2016;17:1833-5.

7. Fuchs I, Gerber B, Samaras P. Monoclonal Gammopathy in the General Practioners's Office. Diagnosis and Treatment of Plasma Cell Myeloma. Praxis (Bern 1994) 2015;104:1141-50. [Abstract]

8. Akar H, Seldin DC, Magnani B, O'Hara C, Berk $\mathrm{JL}$, Schoonmaker $\mathrm{C}$, et al. Quantitative serum free light chain assay in the diagnostic evaluation of $\mathrm{AL}$ amyloidosis. Amyloid 2005;12:210-5.

9. Bilge Caliskan L, Karadeniz T, Ekmekci S, Yilmaz Avcioglu B, Tanrisev M, Kaypak MA, et al. A case of multiple myeloma diagnosed by renal biopsy. BANTAO Journal 2016;14:89-91. 